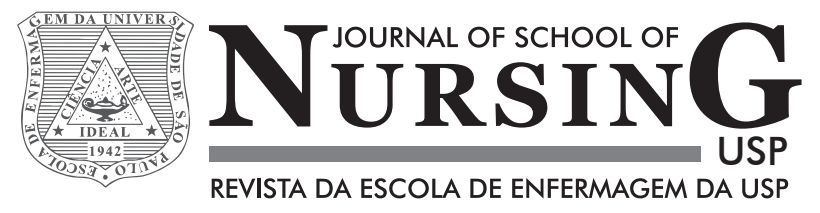

\title{
The family experience of care in chronic situation
}

\author{
Experência familiar de cuidado na situação crônica \\ Experiencia familiar de lo cuidado en situación crónica
}

\author{
Roseney Bellato ${ }^{1}$, Laura Filomena Santos de Araújo², Janderléia Valéria Dolina ${ }^{3}$, Cleciene dos Anjos Musquim, Geovana \\ Hagata de Lima Souza Thaines Corrêa ${ }^{5}$
}

\footnotetext{
${ }^{1,2}$ Faculdade de Enfermagem. Universidade Federal de Mato Grosso, Cuiabá, MT, Brazil.

3,4,5 Nurse. Masters in Nursing. Member of Research Group "Nursing, Health and Citizenship" in University Federal of Mato Grosso, Cuiabá, MT, Brazil.
}

\begin{abstract}
An essay that aims to reflect on the family experience of care in chronic situation, increasing the understanding of the family as the primary caregiver. It is based on comprehensive approach in studies conducted in three matrix searches from family care experiences. We have taken three axes to organize our reflections: a) conformation of family care in chronic situation, highlighting the multiple costs incurred to the family, which can exhaust the potential of care and establish or increase its vulnerability if it is not backed by networks support and sustenance; b) family rearrangements for the care, giving visibility to care cores in which many loved family members share the care, dynamic, plural and changeable way; c) self care modeling family care, pointing to the range of possibilities of the person taking care of diseased conditions supported by people close to them. We learn that the family takes care of itself in everyday life and in the illness experience, creating networks that can provide you support and sustenance. Thus, professionals in health practices should shape up in a longitudinal and very personal way, by reference to the family care, supporting him in what is his own.
\end{abstract}

\section{DESCRIPTORS}

Health care; Family; Family caregivers; Chronic disease; Qualitative research. 


\section{INTRODUCTION}

\section{OUTLINING OUR VISION}

This essay tries to highlight some concepts of family care that have emerged from comprehensive approach studies whose participants were patients and families who were experiencing chronic conditions ${ }^{(1)}$. The reflective effort we made is based on studies carried out by us over the course of seven years, consisting of three major matrix surveys. Some are referred to here, such as publication in an article and as a chapter of a book, so as to make it clear that this knowledge has been gradually developed by us.

We begin from the assumption that families take care of their members, not only to provide and/or recover health, but also to take care of life and for life. We are particularly interested in giving visibility to this type of care in its different forms and places - be it self-care, family environment or through the creation of support networks.

The creation of support networks, composed of people who are close to patients, such as relatives and friends, is necessary in searching for and obtaining resources, in sufficient quantity and quality, in various situations of provision of care experienced over time. In this way, families attempt to ensure the "best in health" for the provision of care to all their members.

Support networks composed of less close relationships and less affectivity, namely those who are outside the family circle, are also necessary; they occur more occasionally, but are no less important for ensuring care maintenance. Health professionals and services may be part of this network, as well as other institutions. Thus, we can state that different levels are implicated and have different effects in the search for the provision of care by families, especially in the experience of chronic conditions.

We considered situations chronic conditions to be those that involve both illness and all care actions required, and the effects of the illness itself and the search for care throughout the lives of patients and their families, which has a certain duration and which we will discuss below.

The aim of this essay was to examine the family experience of care in chronic conditions, expanding the understanding of families as primary care providers. We organized our examination based on three axes: formation of family care in chronic conditions; family rearrangements for care; and self-care shaping family care.

Our purpose was to call on health professionals, especially nurses, to reflect on the participation of health services in networks built by families and emphasize the need for professional practices to be shaped by family care, giving it support. Then perhaps professional practices will be configured as personal, and as a desirable means of care of families and become more effective.

Figure 1 provides a synthesis into a single image of our understanding of care in chronic conditions.

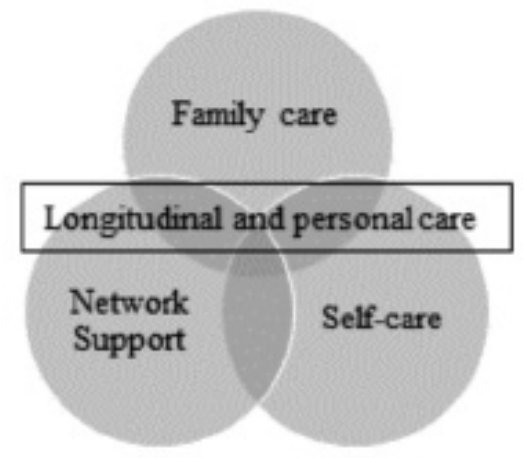

Figure 1 - Rosette of care in chronic conditions.

\section{FORMATION OF FAMILY CARE IN CHRONIC CONDITIONS}

As pointed out above, it is our understanding that families are the primary caregivers for their members, since it is within this environment that a host of care actions is conceived and provided to family members throughout their lives. We mean by "host" the various modes of expression of these care actions, which are generally invisible, because they are subtle, diverse and multiple, going far beyond the way this is usually considered by the health sector.

Families provide care for life, ranging from "emotional interactions necessary for the full development of mental health and the personalities of their members" to learning daily care actions for the body and the environment, as well as those required in cases of illness ${ }^{(2)}$.

However, it is important to mention that families provide care with the resources available to them. This care potential is weakened in situations of vulnerability, which may continue and/or have considerable impact on concrete possibilities for care. Therefore, as the main care providers, families face demands for care in chronic situations, sometimes by more than one family member. Regarding this experience, some studies ${ }^{(1,3-5)}$ have shown the importance of individual provision of care on a continuous basis, whose maintenance requires great effort from families.

If the provision of care falls upon families, it is important to understand how they experience chronic conditions, considering the possibilities of providing daily care according to the different needs that emerge, and also the way they maintain care over time.

Still regarding studies carried out from that perspective, we support authors ${ }^{(6)}$ who have spoken about the importance of considering families as a whole when rearranging their organization, which results in new routines and responses in view of chronic conditions; this movement and its consequences fall upon all family members.

We have considered that, in this experience, families link different elements of care actions, in an attempt to foster well-being for individuals, which goes far beyond a focus on the treatment of diseases. This increased perception of what care means refers to what has been called comprehensiveness of health care ${ }^{(7)}$. However, the idea that su- 
ch comprehensiveness is set in motion by families that take care of their members brought us to shift the discussion from the context of health services to the different contexts of daily life, such as the living spaces where illness and care are experienced by these individuals.

Routine is considered as the main space-time of life experiences, where things happen and make sense, and is referred to as "a sense of belonging to a place," which is actualized by the home. Family routines are where this process occurs in terms of both repetition and sudden and/or unstable events, which need to be rearranged according to the possibilities for each individual and each family ${ }^{(8)}$. Among these events, illnesses mobilize energy and family resources when it comes to the provision of care. The effects of illness need to be managed according to all possible situations of family members individually and families as a whole, which indicates the unique conditions experienced by family members $^{(8)}$.

The naturalization of the care experience by families, which is essential to life, culminates in the allocation of moral responsibility for care, resulting from family history and socialization of family members, among other factors. Thus, it concerns family values and affectivity between people ${ }^{(9)}$. However, this moral responsibility of families includes situations in which health services and professionals have an ethical or legal obligation to provide responses, which are often not very effective. As a result, the provision of care by families is a lonely experience.

A study carried out with a family that was experiencing the illness of two teenagers with sickle-cell anemia ${ }^{(10)}$ showed the professionalization of the mother in the nursing field, with the aim of meeting the health care needs of her children. Families take over several professional care actions at home, and such actions are sometimes indiscriminately passed on to mothers. Likewise, responsibilities originally belonging to professionals are also passed on, and they distance themselves from comprehensive care of children and families.

Some studies ${ }^{(4,10-11)}$ have shown that health services usually act during periods of "exacerbation" of disease, and are requested by families for specific events, and therefore respond in a timely manner. Nevertheless, chronic diseases present their own "highs and lows, movements and densities, expressed in countless ways, in an unstable manner and moving back and forth between the poles of crisis and normality"(8), and are experienced by individuals and families without a specific path between those poles. Families provide daily care, which certainly includes care in compromising conditions; they must manage their own, frequently scarce, resources in order to provide that care ${ }^{(8,12)}$. Therefore, we highlight that families must be considered as an element that also requires care, and for this reason, they must be assisted with addressing the implications of diseases and difficulties that arise from everyday care ${ }^{(5)}$.

However, even in situations of little support for families and under the moral responsibility allocated to them, social and legal obligations for care continue to be assigned to families. Article 3 of the Senior Citizens Statute ${ }^{(13)}$ holds families responsible for care of the elderly, placing them in first place for this obligation, followed by communities, society and the State. However, neither the legal text nor public policies have ensured effective conditions for supporting families in facing this legal delegation of responsibility.

Children and teenagers are situated on the fragile side of life, and guarantees for them are encoded in Brazilian law - the Federal Constitution and the Statute of the Child and Adolescent. In Article 4 of that Statute, families are the first entities held responsible for the achievement of human rights, food, education, sport, leisure and professionalization, among others ${ }^{(14)}$. Similarly, such provisions do not explicitly guarantee concrete conditions for families to take care of children and adolescents.

In view of this commonly imputed liability, families may encounter situations of little support for provision of care that reduce their potential ${ }^{(8)}$. This depletion of potential is even more challenging in cases of chronic diseases, given care needs that are renewed, increased and longer-lasting.

Thus, various expenses are covered by families, resulting from the illness itself and countless demands for provision of care. Broadly speaking, these expenses are presented as: a) wear - understood as the energy and potential of relatives who wear out as a result of caretaking efforts; $b$ ) expenditures - considered as increases in the efforts required that go beyond family routine, which are all the more essential to the provision of care, resulting from recurrent exacerbation of illnesses; and c) waste - understood as the narrowing down of possibilities for family life projects, given the lack of support for families for extended periods of care.

These expenses are of different natures, and can be emotional, economic, or social, resulting from decreases in the potential for family and individual care. In the life of families, these elements strengthen one another, producing negative cascade effects and creating movements that converge and intensify family suffering. They create a vicious circle in which families receive little support ${ }^{(5)}$.

Thus, family vulnerability is created or increased as a result of lack of support for family care on the part of health services and professionals, since family potential decreases over time in view of care demands, which are constantly renewed and increased in chronic conditions.

The definition of chronic conditions proposed by the World Health Organization ${ }^{(15)}$ refers to health complications that commonly require long-term management by health services. We feel that this concept is still based on the individual expression of disease. The understanding of chronic conditions promoted here tries to expand the vision to include the various contingencies experienced by individuals and families as they experience diseases and the actual possibilities of care and of being cared for, emphasizing the ways to support that care. Therefore, addressing the experience of this condition implies "the necessity of understanding sickness as a particular way for individuals to experience disease and what they envision as 'the best 
care.' Likewise, it requires the understanding of life events that place individuals in circuits of vulnerability, more or less wide, which produce several inflexions and changes in their potential for care - their own and that of their families" (16). The circuits of vulnerability include a triad of elements related to the following aspects: a) individual, which alludes to values, beliefs, affections, and impulses; b) social, referring to living and working conditions, culture, economic status, environment, and relationships among generations, gender, and class, among others; and c) programmatic, as it refers to elements that structure and qualify the health system ${ }^{(17)}$.

People are not vulnerable beforehand, but they can be vulnerable at certain times. Thus, vulnerability is not a human condition of "being," but rather a contingency, "being in a state of."

Based on the consideration of families as primary care units that also need to be cared for, we consider that their potential can be an important analyzer of vulnerabilities, especially in situations that require continuous, extended and renewed care ${ }^{(8)}$.

Such an understanding is important for health, since areas of vulnerability arise, to a greater or lesser extent, as a result of the support that health professionals and services may provide to individuals and families, who face countless effects of this experience. Therefore, vulnerability has different durations and intensities, and is neither homogeneous, nor does it arise in specific situations. One can be vulnerable at certain times for the management of specific aspects of life, but not for others; hence, we speak of vulnerabilities in the plural and in context.

It seems that "support" in the experience of sickness and care provision can be an essential element, in both the genesis and the possibility of overcoming vulnerabilities. For such support, the potential for care is implied and reinforced in movements of positivity or negativity, made up of different levels - personal, family, community and health system.

The formal responsibilities of the health system, including ethical and legal obligations regarding care of people and families, reinforce the requirement of helping in the experience of care; however, lack of guarantees of institutional care ${ }^{(8,18)}$ - those provided under the responsibility of health services and professionals - expand and extend situations of family vulnerability; that is, such obligations emphasize the programmatic component in the genesis and maintenance of vulnerabilities ${ }^{(17)}$. We understand that this is one of the major contradictions for professional health services, since their practices should be in synergy with family care, strengthening and expanding its potential, instead of reducing that potential through greater search efforts that are not very fruitful.

Some authors ${ }^{(19,20)}$ argue that health services need to be a reliable source of care of people and families, continuing throughout their illness experiences. Calling this continuity of professional health care "longitudinality," they argue that it is the major challenge to facing chronic conditions in today's world.
But in order for health services and professionals to provide better support for family care, it is necessary to understand the families' own ways of care, with an emphasis on rearrangements of routine in the experience of chronic illness.

\section{FAMILY REARRANGEMENTS FOR CARE IN CHRONIC CONDITIONS}

In the experience of sickness, several family members share family care, in a dynamic, plural and changing way, exchanging the different elements of care needed in various situations. Studies that look at the family experience with care $(16,18,11,21)$ show that families are rearranged by making up care units; this notion attenuates the presence of "main caregivers," conceived by the Ministry of Heal$t^{(22)}$ as the individuals responsible for nearly all the daily work with ill people, their role being to meet needs during periods of sickness or disability.

We assume that the necessary support for the well-being of ill individuals and families takes place on the basis of family relationships, above all, bonds of kinship ${ }^{(23)}$. In that sense, family ties - which differentiate "the family" from "the others" - allow for meeting needs, both material and emotional. There are also those who, although not relatives, have close relationships and are considered to "be part of the family," thus belonging to "us" (24).

Care units are composed of these intertwining, close and unique relationships, as a way of rearrangement of care provided by families, and they represent more or less reliable sources of care provision. These units seek to ensure permanent care, that is, they seek to provide care on a regular basis, with the same duration and intensity. As "places" of care, such units involve a certain emotional proximity and interactions between members who care for and those being cared for, and such interactions are not necessarily cohabitation ${ }^{(18,23)}$.

The structure of family care units may be modified throughout the disease process, with different members making them up, giving them a transient and reversible nature ${ }^{(3)}$. Simultaneous development of other care units in different places is also possible ${ }^{(18)}$. This development goes along with family life dynamics and the daily requirements of care, but not with the logic of previous preparation for care.

This understanding differs from that of the Ministry of Health $^{(25)}$, according to which family care of ill individuals must be planned ahead of time, in order to avoid wearing out the main caregivers. One person may be considered the "reference for the ill" by other family members and/or health professionals; however, that person is, as a general rule, supported by other family members. Therefore, this formation of "family care supported by a network" is dissociated from the idea of main caregivers.

Genograms have been used to highlight the formation of these care units; they were completed on the basis of information provided by families. Genograms allow understanding of the family constellation and/or kinship and/or affectivity across generations, and they show the quality of bonds and the dynamics of the relationship network, as well as the formation of care units ${ }^{(4)}$. 
It is important to understand that correlated elements that have a certain synergy with the family way of life influence the formation of care units. These units have their own shape at different times in life, with unique dynamics in the care of members throughout their lives in families.

Among the elements that have an influence on the formation of family care units, we can mention:

a) emotional closeness, shown by different affections that constitute the ties between members and between members and ill relatives. Such affections are expressed with differing intensity and duration. Blood relations play an important role, as well as position in the family tree, feelings of attraction or repulsion between members, closeness or distance of relationships, and cross-generational or inter-generational ties. These ties are not stable, continuous or permanent, but rather evolving, bringing people closer or pushing them further apart, according to care requirements and possibilities of care, for both families and individuals.

b) family history and significant events that lead to new configurations of families, such as birth, marriage, divorce, and death, among others; such developments bring about new care needs.

c) care potential and conditions for families and their members to carry out care actions. We consider as having care potential those present and available and those who can be deployed by support networks.

d) attitudes toward care, which reflects more subjective aspects that involve family members in different ways, showing different levels of readiness and disposition, knowledge built throughout the experience, and the emotional maturity to deal with sickness, among others.

e) appreciation of care actions that are more or less visible. Moral, social, economic and cultural values, as well as certain types of regulations, are important for this appreciation and for making sense of care.

We also highlight that reciprocity of care is not objective, straightforward or symmetrical, but rather based on the aid received from different family members in different ways. Care is provided in terms of "life scale"; in other wor$\mathrm{ds}$, the amount of time spent providing care may not be the same given back by those who received the initial aid ${ }^{(26)}$. Affectivity and trust give a timeless dimension to care with regard to recompense for family members, becoming a sort of "long-term credit"(26).

It should be noted that families continuously set up and provide care to their members; demands for personal care may increase in situations of sickness, as a result of the needs of ill people. Therefore, the particularities of ill individuals and their sickness also play a role in the formation of family care units and shape them according to their nature and duration.

In this way, illnesses that appear at birth have different care needs than those that are developed at a later stage of life; likewise, the needs resulting from progressive degenerative complications differ from those that go along with chronic diseases, which are more stable over time. Families rearrange themselves and create care units according to these peculiarities.
It is also necessary to consider that ill people also take care of themselves when they are in good enough condition and are mature enough, and this self-care is essential to their well-being.

Hereafter we have tried to emphasize self-care, which is an important element for shaping family care and needs to be considered in its particularities.

\section{SELF-CARE SHAPING FAMILY CARE}

Family rearrangements for care are related to the care potential of each person, which is called self-care. From an experiential perspective, self-care is the way individuals take care of themselves in everyday life in order to achieve well-being. It is comprehensive care supported by significant knowledge built throughout life, which makes sense of their "own care."

Made up of many small and invisible actions and attitudes, self-care is not just related to the state of health or "functional capacity" of people. Therefore, even while experiencing chronic conditions that impose limits and restrictions on their daily lives, individuals can still maintain a certain degree of self-care over time, which varies in terms of quality and possibilities ${ }^{(1)}$.

We understand that self-care is intensely connected to the life experience and care of others. We define experience to be "what happens to us, what touches us. And not what is happening, nor what is being touched" ${ }^{\prime 27)}$. For that reason, self-care is also presented from a relational perspecti$\mathrm{ve}$, as it relates to shared life experiences, encompassing all modes of care and founded on shared knowledge; that is, it is formed by interdependence or co-autonomy. Therefore, it is related to a range of possible personal situations, as well as those that are shared, especially with closely related people.

In contrast, the concept of self-care formulated by the health sector seems to be based on the idea of autonomy and independence, aimed at the emancipation of individuals. This idea is polarized by the concept of dependence, which has a negative and derogatory connotation.

We think that the terms autonomy and independence have to be put into perspective, since social life is created by interdependence by means of care ${ }^{(28-29)}$. Human beings are certainly not, and will never be, completely independent or autonomous, since in certain situations they might need help and support to develop self-care and manage their own lives ${ }^{(1)}$.

If self-care is developed in everyday life and for everyday life, chronic conditions are not separate from it; rather, different levels and duration are increasingly required. Hence, it must be supported in its potential. However, the question must be raised as to whether becoming ill necessarily refers to determining the level of dependence of sick individuals, as this concept offsets their potential for self-care, even if this potential is reduced or subtle.

Another study ${ }^{(1)}$ presented different ways to provide care to families of elderly people with several chronic complications who lived alone by choice. The routines of their families were rearranged in order to create possibilities for 
care of the elderly people, and also to enhance and help their self-care by meeting their needs and being constantly present, even if living in separate houses.

It is necessary to put into perspective the idea that elderly people are dependent because of their fragile condition and limited functional capabilities, which limit their self-care potential, according to the view of "functioning" as being at an organic and merely instrumental level. Therefore, the provision of care must be considered in its several dimensions and always "in context," including the possibility of self-care and family care being in synergy in a dynamic and personalized way.

We also inquired how health services and professionals could support this synergy for the care of people in everyday life. We have shown that continuity of care takes place mainly in the family environment, where people take care of each other, with the available resources and in the situations in which they find themselves. As for professional care, it is limited to the institutional level, being demanded by families at specific times and in a timely manner. When people seek this level of care, they face different kinds of embarrassment, especially when their own ways of providing care are depreciated and disregarded. Such attitudes from health professionals have little effect on contributing to the care of people and families and their peculiarities.

We believe that the domestic settings of families need to be more visible and valued as "places of care," since they are where people live their experiences in everyday life. Therefore, we affirm that professional care must be involved in self-care and family care in order to provide its unique type of support. This provision of care does not set aside the institutional level when it is necessary, given the particularities of certain interventions that can only be performed at that level.

\section{CONCLUSIONS: FOR SUPPORTED CARE}

In this essay, we tried to expand the understanding of families as main caregivers, especially in chronic conditions. We have repeatedly shown that families take care of themselves and their members every day, also in the experience of illness, through the creation of networks to provide support and help.

We highlight the importance of development of these networks in the event of chronic illnesses, where there is an essential need for different types of care actions, which need to be continuous, extending over time, and often become more intense and/or permanent, reducing or draining family care potential. As long as health services and professionals respond ineffectively to these needs, families will need to put forth greater efforts in order to create networks that ensure the effectiveness of care, even if by other means.

When we speak about resources for care, we consider them in a broad sense, since a lot of conditions, feelings, emotions, devices and knowledge are necessary for care provision on a daily basis. Leveraging such resources and making them available according to individual needs results in a complex series of measures that require a lot of effort from families, in addition to the efforts required for everyday life.

Based on the thoughts presented here, we understand that health care in chronic conditions is not shaped solely by families and their support networks, nor by health services and professionals alone. It is rather a combination of different ways of caring put in place to meet the needs for continuous and extended care required by each situation, shaped in a personal manner, as expressed by our rosette of care.

Therefore, we affirm that the synergy of efforts put into care - family care, self-care and networks - must be the reference for health services and professionals in the organization of health care practices so as to be actually and mainly targeted at ill people and families, achieving greater effectiveness and contributing to reducing the pain that is the result of weariness, expenditures and waste of care potential. Only in this way should we call our professional practices "care," in its desirable and substantive dimension.

\section{RESUMO}

Ensaio que tem por objetivo refletir sobre a experiência familiar de cuidado na situação crônica, ampliando a compreensão da família como cuidadora primária. Embasa-se em estudos de abordagem compreensiva realizados em três pesquisas matriciais que abordaram experiências familiares de cuidado. Tomamos três eixos para organizar nossas reflexões: a) conformação do cuidado familiar na situação crônica, destacando os múltiplos custos gerados à família, que podem exaurir seus potenciais de cuidado, instaurando ou ampliando sua vulnerabilidade se não for amparada por redes de apoio e sustentação; b) rearranjos familiares para o cuidado, dando visibilidade aos núcleos de cuidado compartilhados pelos diversos entes familiares, de modo dinâmico, plural e mutável; c) cuidado próprio modelando o cuidado familiar, apontando a gama de condições de possibilidades da pessoa adoecida se cuidar apoiada pelas pessoas que lhe são próximas. Compreendemos que a família cuida de si e de seus entes no bojo da vida, assim como na experiência de adoecimento, tecendo redes que a sustentem ao longo do tempo. As práticas profissionais em saúde precisam modelar-se, então, tendo por referência o cuidado familiar, amparando-o naquilo que lhe seja próprio.

\section{DESCRITORES}

Cuidados à saúde; Família; Cuidadores familiares; Doença crônica; Pesquisa qualitativa.

\section{RESUMEN}

Estudio tuvo como objetivo reflexionar sobre la experiencia familiar de lo cuidado en situación crónica, aumentando la comprensión de la familia como el cuidador principal. Se basa en la comprensión e fuera realizado en tres búsquedas principales sobre experiencias de cuidado familiar. Tomamos três ejes para organizar nuestro piensamento: a) conformación de atención a la familia en situación crónica, esta situación crea múltiples costos para la familia, que puede agotar el potencial de la atención y establecer o aumentar su vulnerabilidad 
si no está respaldada por el apoyo y soporte in sus redes; b) reordenamientos de la familia para el cuidado, dando visibilidad a núcleos del cuidado en los que muchos miembros de la familia lo comparten de manera dinámica, plural y cambiante; c) autocuidado en la familia que hace el cuidado adecuado, apunta a la gama de posibilidades para el cuidar en las condiciones enfermas con el apoyo de las personas cercanas a ellos. Nos enteramos de que la familia ocupa de sí mismo y de su vida cotidiana y, en él, la experiencia de la enfermedad, la creación de redes que las sostien al longo del tiempo. Los profesionales en las prácticas de salud deben tener como referencia el cuidado de la familia, dando el apoyo a él en lo que es la suya.

\section{DESCRIPTORES}

La atención de salud; Familia; Los cuidadores familiares; Enfermedad crónica; La investigación cualitativa.

\section{REFERENCES}

1. Corrêa GHLST, Bellato R, Araújo LFS. Networks to care woven by elderly and her family experiencing situations of chronic illness. Rev Min Enferm. 2014; 18(2): 346-355.

2. Gutierrez DMD, Minayo MCS. Produção de conhecimento sobre cuidados da saúde no âmbito da família. Ciênc Saúde Coletiva. 2010;15(Supl. 1):1497-1508.

3. Bellato R, Araújo LFS, Faria AP, Costa ALRC, Maruyama SAT. Itinerário terapêutico de famílias e redes para o cuidado na condição crônica: alguns pressupostos, In: Pinheiro R, Martins PH, editores. Avaliação em saúde na perspectiva do usuário: uma abordagem multicêntrica. Rio de Janeiro: CEPES/UERJ/UFPE, ABRASCO; 2009. p. 187-194.

4. Hiller M, Bellato R, Araujo LFS. Cuidado familiar à idosa em condição crônica por sofrimento psíquico. Esc Anna Nery. 2011;15(3): 542-549.

5. Araújo LFS, Bellato R, Hiller M. Itinerários terapêuticos de famílias e redes para o cuidado na condição crônica: algumas experiências. In: Pinheiro R, Martins PH, editores. Avaliação em saúde na perspectiva do usuário: uma abordagem multicêntrica. Rio de Janeiro: CEPES/ UERJ/UFPE, ABRASCO; 2009. p. 203-214.

6. Buchbinde M, Longhofer J, MCcue K. Family routines and rituals when a parent has cancer. Fam Syst Health. 2009; 27(3): $213-227$.

7. Cecílio LCO. Apontamentos teórico-conceituais sobre processos avaliativos considerando as múltiplas dimensões da gestão do cuidado em saúde. Interface. 2011; 15(37):589-599.

8. Bellato R, Araújo LFS, Mufato LF, Musquim CA. Mediação e mediadores nos itinerários terapêuticos de pessoas e famílias em Mato Grosso. In: Pinheiro R, Martins PH, editores. Usuários, redes sociais, mediações e integralidade em saúde, Rio de Janeiro: UERJ, IMS, LAPPIS; 2011 . p. 177-184.

9. Alves JMPM. Vidas de Cuidado(s): uma análise sociológica do papel dos cuidadores informais [dissertação]. Coimbra (PT): Faculdade de Economia da Universidade de Coimbra, 2011.

10. Silva AH, Bellato R, Araújo LFS. Cotidiano de família que experiencia a condição crônica por anemia falciforme em dois adolescentes. Rev. Eletr. Enf. 2013;15(2): 437-446.

11. Musquim CA, Araújo LFS, Bellato R, Dolina JV. Genograma e ecomapa: desenhando itinerários terapêuticos de família em condição crônica. Rev. Eletr. Enf. 2013;15(3): 656-666.

12. Dolina JV, Bellato R, Araújo LFS. Research Experience with a Person Going through the Process of Dying and Death. Journal Palliative Medicine. 2014; 17(2):244-245.

13. Brasil. Lei n.10.741 de 10 de outubro de 2003. Dispõe sobre o estatuto do idoso e dá outras providências. Parecer $\mathrm{n}^{\circ} 1301$, de 2003, Brasília, DF, 2003.

14. Brasil. Ministério da saúde. Estatuto da criança e do adolescente, Brasília, DF; 2008.

15. Organização mundial de saúde. Cuidados inovadores para as condições crônicas: componentes estruturais para ação. Relatório mundial, Brasília, DF: OMS; 2003.

16. Correa GHLST, Bellato R, Araujo LFS. Different forms of family care for elderly in chronic situation. Cienc Cuid Saúde. 2015; 14(1):796804.

17. Ayres JRCM, França JI, Calazans GJ, Saletti FH. O conceito de vulnerabilidade e as práticas em saúde: novas perspectivas e desafios. In: Czeresnia D, Freitas C M. Promoção da saúde. Rio de Janeiro: FIOCRUZ; 2003. p. 117-139.

18. Correa GHLST, Bellato R, Araujo LFS, Hiller M. Itinerário Terapêutico de idosa em sofrimento psíquico e família. Cienc Cuid Saúde. 2011; 10(2):274-283.

19. Starfield B. Atenção primária: equilíbrio entre necessidades de saúde, serviços e tecnologia. Brasília, DF: Unesco, Ministério da Saúde; 2002.

20. Mendes EV. O cuidado das condições crônicas na atenção primária à saúde: o imperativo da consolidação da estratégia da saúde da família. Brasília, DF: Organização Pan-Americana da Saúde; 2012.

21. Almeida KBA, Araújo LFS, Bellato. Family caregiving in chronic illness: a young person's experience. Rev. Min Enferm. 2014; 18(3):724732.

22. Brasil. Secretaria especial dos direitos humanos, Subsecretaria de promoção e defesa dos direitos humanos. Cuidar melhor e evitar a violência: Manual do Cuidador da Pessoa Idosa. Brasília: Série A. Normas e Manuais Técnicos; 2008.

23. Mufato LF, Araújo LFS, Bellato R, Nepomuceno MAS.(Re)organização no cotidiano familiar devido às repercussões da condição crônica por câncer. Cienc Cuid Saúde. 2012; 11(1): 89-97.

24. Portugal S. A alquimia do parentesco. Para uma discussão da relação entre dádiva e família. Rev Realis. 2013; 3(1):153-174. 
25. Brasil. Ministério da saúde. Secretaria de atenção à saúde, Secretaria de gestão do trabalho e da educação na saúde. Guia prático do cuidador. Brasília: Série A. Normas e Manuais Técnicos, 2008.

26. Portugal S. O que faz mover as redes sociais? Uma análise das normas e dos laços. Revista Crítica de Ciências Sociais. 2007; 79(1): 35-36.

27. Bondía JL. Notas sobre a experiência e o saber de experiência. Rev Bras Educ. 2002; 19: 20-28.

28. Medeiros M, Diniz D. Envelhecimento e deficiência. SérieAnis. 2004; 36. Brasília: Letras Livres. p. 1-8.

29. Milligan C. There's no place like home: Place and care in an ageing society. Ageing Soc. 2009;30(5): 917-919. 